\title{
HSTC Bulletin
}

Journal of the History of Canadian Science, Technology and Medecine

\section{The (Mild) Winds of Change}

Volume 3, numéro 4 (12), august 1979

URI : https://id.erudit.org/iderudit/1081877ar

DOI : https://doi.org/10.7202/1081877ar

Aller au sommaire du numéro

Éditeur(s)

HSTC Publications

ISSN

0228-0086 (imprimé)

1918-7742 (numérique)

Découvrir la revue

Citer ce document

(1979). The (Mild) Winds of Change. HSTC Bulletin, 3(4), 1-1.

https://doi.org/10.7202/1081877ar

All Rights Reserved (c) Canadian Science and Technology Historical Association / Ce document est protégé par la loi sur le droit d'auteur. L’utilisation des Association pour l'histoire de la science et de la technologie au Canada, 1979 services d’Érudit (y compris la reproduction) est assujettie à sa politique d'utilisation que vous pouvez consulter en ligne.

https://apropos.erudit.org/fr/usagers/politique-dutilisation/ 


\section{HSTC}

\section{BULLETIN}

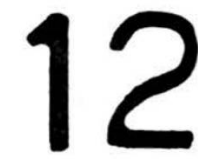

AUGUST 1979 AOUT

\section{THE (MILD) WINDS OF CHANGE}

With this issue, the Bulletin completes its third full year of publication. The field has moved steadily forward in this time and one can read with satisfaction the growing list of recent publications. In our last number we discussed the idea of an organization for historians of Canadian science and technology and evinced some hope that something constructive might come out of the annual meeting of the Canadian Society for History and Philosophy of Science. On the positive side, two 'Canadianists' were elected to the society's Council (R.A. Jarrell as second vice-president and A.E. Roos as councillor) but an effortito have Canadian studies recognized as a sub-group again failed to elicit interest. Nonetheless, the discussion opened up some long-festering wounds of the society. There seemed to be, on the part of some members present, almost a fear of the 'Canadianists,' as if the energy shown by our group might somehow endanger the species of non-Canadianists. of course, this is neither the case nor the intention. The net result was a clearing of the air, but no institutional home. The informal approach has stood us in good stead so far and it will have to be that way for some time to come.

One positive action we at HSTC Publications are attempting to make is the conversion to the status of non-profit corporation. Our publications board is now holding discussions on some new publishing initiatives for the field. We shall keep you posted on our progress in coming issues.

Quarterly Newletter for the History of Science and Technology of Canada
Publication trimestrielle pour l'histoire des sciences et de la technologie canadiennes 